\title{
Approval and Introduction of the International Financial Reporting Standards (IFRS) in Georgia: Challenges and Perspectives
}

Levan Sabauri*

Department of Accounting and Audit, Ivane Javakhishvili Tbilisi State University, Tbilisi, Georgia

\begin{abstract}
In this study we discuss how important introduction of the International Financial Reporting Standards is for the Georgian auditors and how the standards affect transparency and the shareholders' attitude to the management's representations. The target group is the external (independent) auditors, and the randomly selected audit firms in Georgia. The initial data were gathered by means of the questionnaire distributed among the addressees and checked by means of the chi-square test and the statistical package for the social sciences. The findings confirmed that the International Financial Reporting Standards affect transparency and the shareholders' attitude to the management's representations. The study recommends training of the staff for better application of the standards preconditioning the shareholders' loyalty.
\end{abstract}

Keywords: Auditors; Financial statement; Investors; Multinational company; International accounting standards

\section{Introduction}

The financial statement prepared in line with the applicable national laws is of great importance to the users, who require the appropriate accounting information for the purpose of investment etc. decisions. The information given in the financial statement is useful, if "the economic essence", i.e., significance and reliability of an organization is accurately and fairly portrayed and to make it possible to compare it with similar organizations [1]. The accounting information given in the quality financial statement is expedient in terms of appropriate distribution of resources by reduction of the spread of the asymmetric information and improved pricing of the securities.

Therefore, the quality financial statement makes it possible to avoid delayed recognition of loss, creation of additional reserves and downplaying unstable incomes for the sole purpose of creating impression of a stable and consistent growth [2]. Consequently, the financial statements prepared according to the international standards are to set out the events taking place within a certain period, which is very important since each user, be it a person or an organization wants to know what is in store for their investments, as well as the organizations they want to invest in.

The purpose of the International Accounting Standards Committee established in 1973 was harmonization of the national accounting standards, determination of the uniform accounting standards in order to narrow the gap between the international accounting principles and practice. The committee suggested the International Accounting Standard (IAS), which envisaged determination of the uniform accounting principles in the next 20 years [3]. In April 2001, the International Accounting Standards Board (IASB) took over introduction of the International Accounting Standards, which have been updated ever since and called the International Financial Reporting Standards (IFRS).

It was due to the recognition of the appropriate financial reporting that various countries agreed to introduce the International Financial Reporting Standards. Year 2002 marked the breakthrough for the EU adopted the law stating that the companies listed at the European stock exchanges must apply the International Financial Reporting Standards in preparing the single financial statement. The law effective since year 2005 has affected over 8000 companies in 30 countries, such as France,
Germany, Italy, Spain and the UK. Introduction of the IFRS in Europe means that in the preparation and submission of the joint financial statement, the companies listed at the European stock exchanges should apply the IFRS instead of the National Standards of Accounting [4].

A number of non-European countries have also been applying IFRS, which by 2005 had become obligatory in quite a few countries in Africa, Asia and Latin America. Besides, the countries like Australia, Hong-Kong, New Zealand, the Philippines and Singapore introduced the national accounting standards harmonized with the IFRS [5]. According to a study, by year 2008, approximately 80 States requested the companies listed at their stock exchanges to apply IFRS in the preparation and submission of their financial statements. The IFRS are applied in many other countries, as well.

In 1999, the Georgian parliament adopted the "On Regulating the Accounting and Reporting". Under the law, from January 1, 2000, the joint stock companies were to apply the international standards in their accounting and financial reporting, while the limited liability companies, limited partnerships, general partnerships and cooperatives were obligated to apply the Standards from January 1, 2001.

It's nearly 18 years since introduction of the International Accounting Standards in Georgia. However, it's hardly possible to assert that the national accounting system is streamlined. Neither do we know whether the International Financial Reporting Standards have been instrumental in terms of preparation of more accurate financial statements in this country. It should be said though that the research and survey have shown that their introduction has been positive where the global investment and investment analysts' confidence in the companies' financial statements are concerned. The International Financial Reporting Standards rely on the universally

*Corresponding author: Levan Sabauri, Associate Professor, Department of Accounting and Audit, Ivane Javakhishvili Tbilisi State University, Tbilisi, Georgia, Tel: +995577555323; E-mail: sabaurilevan@gmail.com

Received April 10, 2018; Accepted April 17, 2018; Published April 25, 2018

Citation: Sabauri L (2018) Approval and Introduction of the International Financial Reporting Standards (IFRS) in Georgia: Challenges and Perspectives. J Account Mark 7: 268. doi: 10.4172/2168-9601.1000268

Copyright: ( 2018 Sabauri L. This is an open-access article distributed under the terms of the Creative Commons Attribution License, which permits unrestricted use, distribution, and reproduction in any medium, provided the original author and source are credited. 
recognized principles, and as against those underpinning the financials statements prepared in some countries, the IFRS do not give issuers of the securities detailed recommendations how to draw up the financial statements. In this study, we discuss in what way the International Financial Reporting Standards affect the external auditors' work in Georgia

\section{Statement of Problem}

A number of scholars put down the hullabaloo about introduction of the uniform standard to the globalization and an increasing integration of the global markets [6]. Calls for adoption of the International Standards of Financial Reporting became especially strong after the "Enron" oil company scandal in 2002 in America [7]. The wobbly accounting standards allowed the "Enron's" wily management to conceal huge loss and deceive investors who suffered tremendous loss after the company went bust. Application of the wobble accounting standards leads not only to the financial manipulation but creates problems, such as:

- Complex comparison of financial statements of two firms operating in different countries;

- Significant expenses required for obtainment of information due to incomplete representation of facts;

- Wrong decisions made due to application of inappropriately understood financial statement.

In analyzing the problems caused by application of wobble accounting standards, the following should be taken into account: processes accompanying introduction of the International Financial Reporting Standards in Georgia; the relevant major issues; problems facing the auditors. It's those issues the study deals with.

\section{Objectives of the Study}

The general objective of the study is to determine the influence and usefulness of IFRS for auditors in Georgia.

\section{Hypotheses of the Study}

The study includes the hypotheses below:

1. Significant correlation between introduction of the International Financial Reporting Standards and transparent management of a company;

2. Significant correlation between introduction of the International Financial Reporting Standards and the shareholders' confidence in the management's representations.

\section{Shortcomings of the Study}

The biggest shortcoming of this study was a limited term set to the respondents for filling out the questionnaire. The problem was that their crowded schedule did not allow them to collect more data from the participant firms, while some of the companies refused to participate in the research.

\section{Methodology}

Although the ultimate goal of the study was adoption and establishment of the International Financial Reporting Standards, we focused on their influence on the auditors and, in broader terms, the audit in Georgia [8]. The target group included the independent auditors operating in Georgia, which of course implies certain limitation. For the purpose of the study we applied a random selection method, which implies giving equal opportunities to the members of the target group. We applied the method to the staff and partners of an audit firm operating in Georgia at the time of research. Besides, we applied the initial and secondary data collection method. The former was gathered by means of the questionnaire, while the latter were taken from the journals, publications, manuals and Internet. The questionnaire was the key tool in terms of gathering the information relevant to the study. The questionnaire was made up of four A, B, C, D parts. " $\mathrm{A}$ " contained the respondents' brief profiles, while " $\mathrm{B}$ ", "C" and " $\mathrm{D}$ " allowed for a single answer to each question concerning major issues.

The data gathered for analysis were obtained as a result of a survey taken by means of the questionnaire. The study focuses on the auditors employed with 17 Georgian audit firms. Out of 135 (one hundred and thirty-five) 120 (one hundred and twenty) questionnaires were accepted.

Table 1 shows that positive correlation between introduction of the International Financial Reporting Standards and transparent management is weak. Therefore we may conclude that by representing more financial information, introduction of the International Financial Reporting Standards will lead to more transparent management of companies.

\section{Result and Discussion}

\section{Chi-square testing of the first hypothesis}

There is no correlation between introduction of the International Financial Reporting Standards and transparent management of companies.

Table 2 shows that the calculated chi-square is 190.098 at 5\% level. However, the chi-square value given in the table is 5.99.

How to make a decision: if the calculated chi-square is less than the one in the table, the zero hypothesis should be preserved, otherwise it should be rejected. As the result above shows, the calculated chi-square (97.203) is over its value given in the table (5.99) at $5 \%$ value level, degree of freedom -2 . So, the zero hypotheses should be

\begin{tabular}{|l|l|c|c|}
\hline & & $\begin{array}{c}\text { Comparison of the standards } \\
\text { initially applied by the companies } \\
\text { to the IFRS: which are better? }\end{array}$ & $\begin{array}{c}\text { Do you think introduction of IFRS in Georgia } \\
\text { has lead to a more accurate representation of } \\
\text { financial information by the companies? }\end{array}$ \\
\hline $\begin{array}{l}\text { Comparison of the standards initially applied by } \\
\text { the companies to the IFRS: which are better? }\end{array}$ & Pearson correlation & 1 \\
\hline & Sig. (2-Tailed) & \\
\hline $\begin{array}{l}\text { Do you think introduction of IFRS in Georgia } \\
\text { has lead to a more accurate representation of } \\
\text { financial information by the companies? }\end{array}$ & Pearson correlation & 112 \\
\hline & Sig. (2-Tailed) & 0.056 \\
\hline & $\mathrm{N}$ & 0.544 \\
\hline
\end{tabular}

Table 1: Pearson correlation coefficient. 
Citation: Sabauri L (2018) Approval and Introduction of the International Financial Reporting Standards (IFRS) in Georgia: Challenges and Perspectives. J Account Mark 7: 268. doi: 10.4172/2168-9601.1000268

Page 3 of 4

rejected, which means that there is correlation between introduction of the International Financial Reporting Standards and transparent management of companies.

\section{Hypothesis 2}

There is no correlation between introduction of the International Financial Reporting Standards and the shareholders' confidence in the management's representations.

Table 3 shows that positive correlation between introduction of the International Financial Reporting Standards and shareholders' confidence in the management's representations is weak. Therefore we may conclude that by as a result of introduction of the International Financial Reporting Standards, the shareholders' confidence in the financial statements of companies has built up.

Chi-square test: There is no correlation between introduction of the International Financial Reporting Standards and the shareholders' confidence in the management's representations (Table 4).

Table 5 shows that the calculated chi-square is 97.203 at $5 \%$ level. However, the chi-square value given in the table is 4.49 .

How to make a decision: If the calculated chi-square is less than the one in the table, the zero hypothesis should be preserved, otherwise it should be rejected. As the result above shows, the calculated chisquare (97.203) is over its value given in the table (9.49) at $5 \%$ value level, degree of freedom -4 . So, the zero hypothesis should be rejected, which means that there is correlation between introduction of the International Financial Reporting Standards and the shareholders' confidence in the management's representations.

\section{Conclusion}

The analysis of the data makes it possible to conclude: first of all, it turned out that the environment, i.e., availability of the capital market in Georgia and the economic growth, as well as the accounting organizations and amendments to the governing laws rather than inefficiency of the applied standards have lead to introduction and application of the International Financial Reporting Standards.

Also, it was found that difficulties in terms of harmonization and transition from the generally recognized accounting principles applied in Georgia, the ethical environment in the country and training of the relevant staff, which emerged after introduction of the International Financial Reporting Standards, complicate their due application.

Besides, we may conclude that introduction and application of the International Financial Reporting Standards in Georgia is to some extent useful to the shareholders, as the companies divulge more financial information.

The study also reflects the auditors' attitude to introduction and application of the International Financial Reporting Standards. They think that compared to the ones earlier applied in Georgia, the IFRS are more difficult and time consuming. However, they are better. The International Financial Reporting Standards developed in the industrial countries are also applicable in the developing ones, since they make the information presented by companies more reliable.

Finally, testing the hypotheses by Pearson correlation and chisquare methods testified to the correlation between introduction of the International Financial Reporting Standards and transparent

\begin{tabular}{|l|l|}
\hline & Do you think introduction of IFRS in Georgia has lead to a more accurate representation of financial information by the firms? \\
\hline Chi-square & 190.099 \\
\hline Df & 2 \\
\hline Asymp. Sig. & 0.000 \\
\hline
\end{tabular}

Table 2: Test statistics.

\begin{tabular}{|c|c|c|c|}
\hline & & $\begin{array}{l}\text { Comparison of the standards } \\
\text { initially applied by the companies } \\
\text { to the IFRS: which are better? }\end{array}$ & $\begin{array}{l}\text { Do you think introduction of IFRS in Georgia } \\
\text { has lead to a more accurate representation of } \\
\text { financial information by the companies? }\end{array}$ \\
\hline \multirow{3}{*}{$\begin{array}{l}\text { Comparison of the standards initially applied by } \\
\text { the companies to the IFRS: which are better? }\end{array}$} & Pearson correlation & 1 & 0.038 \\
\hline & Sig. (2-Tailed) & & 0.682 \\
\hline & $\mathrm{N}$ & 112 & 112 \\
\hline \multirow{3}{*}{$\begin{array}{l}\text { Do you think introduction of IFRS in Georgia } \\
\text { has lead to a more accurate representation of } \\
\text { financial information by the companies? }\end{array}$} & Pearson correlation & 0.038 & 1 \\
\hline & Sig. (2-Tailed) & 0.682 & \\
\hline & $\mathrm{N}$ & 112 & 112 \\
\hline
\end{tabular}

Table 3: Pearson correlation coefficient.

\begin{tabular}{|c|c|c|c|}
\hline & Studied & Anticipated \\
\hline Unconditional consent & 29 & 24.6 & 24.6 \\
\hline Consent & 56 & 24.6 & 31.4 \\
\hline No answer & 15 & 24.6 & -9.6 \\
\hline Disagree & 9 & 24.6 \\
\hline Fully disagree & 3 & -15.6 \\
\hline
\end{tabular}

Table 4: Introduction of the international financial reporting standards has increased the shareholders' confidence in the financial statements.

\begin{tabular}{|l|l|}
\hline & Introduction of IFRS in Georgia increases the shareholders' confidence in the financial statements \\
\hline Chi-square & 97.203 \\
\hline Df & 4 \\
\hline Asymp. Sig. & 0.000 \\
\hline
\end{tabular}

Table 5: Test statistics. 
Citation: Sabauri L (2018) Approval and Introduction of the International Financial Reporting Standards (IFRS) in Georgia: Challenges and Perspectives. J Account Mark 7: 268. doi: 10.4172/2168-9601.1000268

Page 4 of 4

management of the companies, as well as the shareholders' confidence in the management's representations.

The law "On Accounting, Reporting and Auditing" adopted on 24 June 2016, led to setting up of the Service for Accounting, Reporting and Auditing Supervision. In order to support the economic decisionmaking, the service aims at creation of the area containing financial and management information, whose reliability must be built up by means of the supervisory system and based on the international standards. Regardless of a number of reforms, implemented by the Service for Accounting, Reporting and Auditing Supervision, it still faces major challenges. It is the response to those challenges that the recommendations in the final part of the study concern.

\section{Recommendations}

Relying on the major issues emerging in the study, the following recommendations were developed: although most of the companies listed at the stock exchanges prepare their financial statements according to the IFRS, the scarcity of the qualified staff is still a problem. Understandingly, introduction of the International Financial Reporting Standards calls for training of the staff by the relevant firms or the State. Given the World Bank opinion that the Georgian stock exchange is inadequately regulated, for the time being preparation of financial statements may be voluntary.

Also, for the purpose of compliance with the International Accounting Standards, the regulatory bodies in Georgia, such as the Service for Accounting, Reporting and Auditing Supervision, the National Bank, Ministry of Finance, professional organizations etc. bodies responsible for the financial statements of firms should introduce certain tools, such as sanctioning the firms that failed in terms of the compliance with the standards and supporting those which did not.

For the purpose of safety of business in this country, the Service for Accounting, Reporting and Auditing Supervision in charge of defining the accounting and auditing standards, monitoring compliance of the financial reporting and accounting with the international standards, control over auditing and reporting and imposition of sanctions should be legally granted more powers and better financed.

The service should focus on technical staff, training of inspectors/ experts, administrative support and appropriate logistics.

\section{Involvement of stakeholders}

The system of standards and monitoring with due consideration of the stakeholders' agreed opinion should be created. For the purpose of bridging the differences and increased probability of accounting standards developed by the committee, the draft standards should be distributed among the professionals and public at large.

\section{Support to adoption of IFRS by the firms}

In case of compliance with the International Financial Reporting Standards (application of IFRS etc. relevant requirements on the regular basis), the regulatory bodies may introduce the rewards, such as simplified listing at the stock exchange or pecuniary or non-pecuniary awards.

\section{Improved instruction in accounting}

For the purpose of achievement of the basic quality instruction in accounting and auditing, all the universities in Georgia should have the relevant curriculum and the instructors' training plan in place fully meeting the market requirements.

\section{References}

1. Godfrey J, Hodgson A, Tarca A, Hamilton J, Holmes S (2010) Accounting theory.

2. Chen $H$, Tang $Q$, Jiang $Y$, Lin $Z$ (2010) The role of international financial reporting standards in accounting quality: Evidence from the European Union. $\mathrm{J}$ Int Financial Manag Account 21: 220-278.

3. Barth ME, Landsman WR, Lang MH (2008) International accounting standards and accounting quality. J Account Res 46: 467-498.

4. Kurt PR, Cornelis AR (2015) International Financial Reporting Standards (IFRS), pp: 13-14

5. Kurt PR, Cornelis AR (2015) Framework, standards and interpretations of IFRS

6. Ball R (2006) International Financial Reporting Standards (IFRS): Pros and cons for investors. Accounting and Business Research 36: 5-22.

7. American Institute of Certified Public Accountants (2013) International Financial Reporting Standards (IFRS).

8. Lantto AM, Sahlström P (2009) Impact of International Financial Reporting Standard adoption on key financial ratios. Accounting and Finance 49: 341-361. 